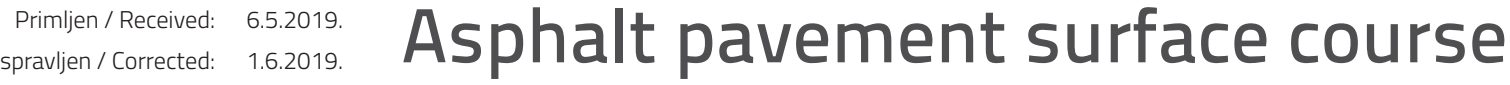 \\ Prihvaćen / Accepted: 3.6.2019.
}

Dostupno online / Available online: 31.8.2019.

Authors:

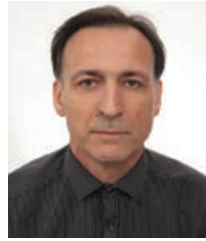

Assist.Prof. Miroslav Šimun, PhD. CE Zagreb University of Applied Sciences Department of Civil Engineering msimun@tvz.hr

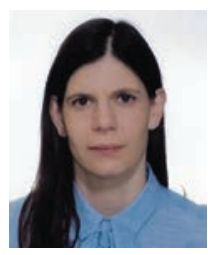

Sandra Mihalinac, MCE

Zagreb University of Applied Sciences Department of Civil Engineering sandra.mihalinac@tvz.hr
Miroslav Šimun, Sandra Mihalinac

Research Paper

\section{Asphalt pavement surface course with recycled rubber}

After the end of their use in road traffic, car tires can be used in road construction as an addition to bitumen mixtures. By adding recycled rubber, bitumen properties are improved and better behaviour of placed asphalt is achieved (lower sensitivity to water action and cracking, and good skid resistance). Results obtained on three asphalt-pavement test sections, with and without addition of rubber in bitumen, are analysed after eleven years of road use. Characteristics of asphalt with different proportions of recycled rubber in bitumen and polymer modified bitumen are analysed.

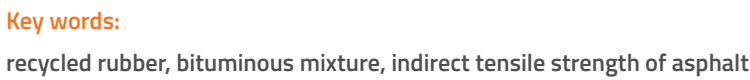

recycled rubber, bituminous mixture, indirect tensile strength of asphalt

Prethodno priopćenje

\section{Miroslav Šimun, Sandra Mihalinac}

\section{Završni sloj asfaltnoga kolnika s dodatkom reciklirane gume}

Nakon što se prestanu upotrebljavati za prometovanje po kolnicima, umjesto da se odlažu na odlagalište otpada automobilske se gume, mogu koristiti u cestogradnji kao dodatak bitumenskoj mješavini. Dodavanjem reciklirane gume poboljšavaju se svojstava bitumena te se postižu bolja eksploatacijska svojstva asfalta (manja osjetljivost na djelovanje vode i pojavu pukotina te dobre hvatljivosti vozne površine). Nakon jedanaest godina eksploatacije analizirani su rezultati na trima pokusnim dionicama asfaltnoga kolnika s dodatkom gume u bitumenu i bez njega. Analizirana su svojstva asfalta s različitim udjelom reciklirane gume u cestograđevnome i polimerom modificiranome bitumenu.

Ključne riječi:

reciklirana guma, bitumenska mješavina, indirektna vlačna čvrstoća asfalta

Vorherige Mitteilung

Miroslav Šimun, Sandra Mihalinac

\section{Deckschicht der Asphaltfahrbahn mit recyceltem Gummi}

Nachdem Autoreifen nicht mehr für den Straßenverkehr verwendet werden, können sie im Straßenbau als Zusatz zur bituminösen Mischung verwendet werden, anstatt auf einer Mülldeponie entsorgt zu werden. Der Zusatz von recyceltem Gummi verbessert die Eigenschaften von Bitumen und es werden bessere Nutzungseigenschaften von Asphalt (geringere Anfälligkeit für Wasser und Risse und gute Griffigkeit der befahrbaren Oberfläche) erzielt. Nach elfjähriger Nutzung wurden die Ergebnisse der drei Teststrecken für Asphaltfahrbahnen mit und ohne Gummizusatz im Bitumen analysiert. Die Eigenschaften des Asphalts mit unterschiedlichen Gehalten an recyceltem Gummi im Straßenbau und im polymermodifizierten Bitumen wurden analysiert.

Schlüsselwörter:

recyceltes Gummi, bituminöse Mischung, indirekte Zugfestigkeit von Asphalt 


\section{Introduction}

Every new technology for the application of materials that will encourage recycling of any kind of waste is highly welcome in the 21st century [1]. Car tires can be reused as a building material in the form of bituminous mixtures for pavement surfaces and as material for the manufacture of concrete elements and assemblies [2]. Recycled tire rubber in asphalt contributes to sustainable development by generating new value from manufactured products [3]. According to the Ordinance on management of waste tires [4], a tire is any product placed on the market as an independent product or as a component of another product. Waste tire recycling is also positive from the point of view of responsible waste management and environmental protection, precisely because of the fact that car tires are produced in large quantities and are considered a very problematic category of waste, as shown in $[5,6]$.

Given that only $5 \%$ of recycled tires are used for civil engineering purposes, the aim is to increase this percentage with new technologies and products that will enable adequate use of recycled tires [7]. According to the EU Directive 1999/31/EC [8], the disposal of entire car tires in the environment has been banned since 2003, and since 2006 the disposal of tire parts has been prohibited as well. Although in 1992, $65 \%$ of used tires were dumped at landfills in 12 EU countries, and only $35 \%$ were disposed of in some other way, the situation was completely different in 2002. In the 15 countries of the EU, $65 \%$ of waste tires were disposed of by means of protection (tire renewal), recycling, use for energy purposes or export for reuse, and less than $35 \%$ ended at landfills [9]. Relevant data show that between 1994 and 2011 the amount of recycled tires has increased from $20 \%$ to $95 \%$ in a number of countries around the world [10]. In the early $20^{\text {th }}$ century, experiments were carried out to improve the quality of asphalt mixtures by adding rubber granules to natural aggregate. The results of numerous tests, as well as an extensive practical experience, justified the addition of rubber granules to bituminous mixtures, as this reduces the sensitivity of asphalt pavements to cracking and extends useful life. Contemporary use of recycled waste rubber in asphalt started in 1960 when engineer Charles McDonald, concerned about the high cost of road maintenance and expensive cracking repairs in asphalt, developed a "wet process - adding granules of waste rubber to bitumen" when performing surface treatment as a part of maintenance of asphalt pavements [11].

Recycled car tire particles in bituminous mixtures may be either added to bitumen (wet process) or to aggregate (dry process). Rubber asphalt has been introduced to produce different types of bituminous mixtures and is formed by either "dry" or "wet" process. In the "wet" process, crumbs and binder are mixed to form a homogeneous mixture of bitumen and rubber, which is then mixed with aggregate [13]. In the "dry" process, the crumbs are mixed directly with aggregates to produce an asphalt mixture with rubber. Compared to the "wet" process, the reaction time in the "dry" process is considerably shorter due to larger size of rubber crumb particles [14]. Numerous, mostly foreign, researchers have studied the ways in which asphalt properties are affected by rubber [12-19, 20-26]. Tai Nguyen and Nhan Tran [15] have confirmed that asphalt with rubber produced by the "dry" process can be used in flexible pavements to improve rutting properties. In their paper, Shen et al. [16] studied the crumb rubber and binder interaction based on the "dry" procedure. A ten-year survey by the Florida Ministry of Transport [17] has revealed that the "wet" process yields better results compared to the "dry" process.

The thermal aging process of binder modified with tire and elastomeric bitumen was described by Xiang et al. in [18]. Laboratory and field tests conducted by Xiao et al. [19] show that the durability and rutting resistance increases by adding rubber to asphalt. The impact on rutting resistance and stiffness modulus of polymer modified bitumen ( $\mathrm{PmB}$ ) used in pavement waterproofing is described in [20]. For further research, the authors suggest assessment of impact of waste tire addition on asphalt properties. Studies by Paja et al. [21] show that noise is reduced by $3 \mathrm{~dB}$ if asphalt with rubber is used, thus facilitating life in the environments where people work and live. Experimental results of the research carried out by Franesqiu et al. [22] show that rubber asphalt significantly improves moisture resistance, rutting resistance, water resistance, and stability to water damage, while also meeting standard specifications for pavements, and offering a sufficient dynamic modulus of rigidity compared to the similar asphalt without waste tire.

The experience gained by the California Ministry of Transport over four decades shows that asphalt rubber products can be durable and extend lifetime of asphalt if they are properly manufactured and processed [23]. The aim of using recycled car tires in asphalt is to achieve better designed physico-mechanical properties of the asphalt layer, and better characteristics of the pavement surface in use. The addition of rubber to bitumen results in increased penetration values before and after short term aging and UV radiation. Lower viscosity of rubber modified bitumen results in better workability and binder construction, as noted by Rasool et al. [24]. According to testing presented in [25] the degree of degradation of crumb rubber affects its dispersion and interaction with the modified elastomeric bitumen, which positively influences production of modified bitumen. Sri Wulandary and Tajandra [26] have established that addition of rubber increases the quality of asphalt mixture, and allows the use of lower bitumen content in asphalt mixture when waste tire is added as modifier [26].

\section{Application of recycled rubber in asphalt}

A steadily increasing use of polymer modified bitumen (PmB) in asphalt pavements has imposed the need to conduct tests aimed at determining the extent to which the properties of ordinary traditional bitumen can be improved, in order to make savings with regard to the use of expensive asphalt with $\mathrm{PmB}$ in the surface layer of the road. In 2006, research was carried 
Table 1. Data on average annual and average summer daily traffic

\begin{tabular}{|c|c|c|c|c|c|c|c|c|}
\hline \multirow{2}{*}{ Road section } & \multirow{2}{*}{$\begin{array}{l}\text { Counter } \\
\text { location }\end{array}$} & \multirow{2}{*}{$\begin{array}{c}\text { Traffic counting } \\
\text { year }\end{array}$} & \multicolumn{2}{|c|}{ Traffic } & \multicolumn{2}{|c|}{ Traffic increase [\%] } & \multirow{2}{*}{$\begin{array}{l}\text { Traffic count } \\
\text { segment }\end{array}$} & \multirow{2}{*}{$\begin{array}{c}\text { Length } \\
{[\mathrm{km}]}\end{array}$} \\
\hline & & & AADT & ASDT & AADT & ASDT & & \\
\hline \multirow{2}{*}{ Zagreb bypass } & \multirow{2}{*}{ - } & 2008 [27] & 54222 & 64210 & \multirow{2}{*}{0.18} & \multirow{2}{*}{9.13} & \multirow{2}{*}{$\begin{array}{c}\text { Jankomir } \\
\text { intersection - } \\
\text { Lučko intersection }\end{array}$} & \multirow{2}{*}{5.1} \\
\hline & & 2015 [27] & 54317 & 70074 & & & & \\
\hline \multirow{3}{*}{ A3/M3 } & \multirow{3}{*}{$\begin{array}{c}3302 \\
\text { Kutina - east }\end{array}$} & 2006 [28] & 16220 & 23819 & \multirow{2}{*}{18.71} & \multirow{2}{*}{16.15} & \multirow{3}{*}{$\begin{array}{l}\text { Kutina intersection } \\
\text { - Novska } \\
\text { intersection }\end{array}$} & \multirow{3}{*}{21.1} \\
\hline & & 2016 [28] & 19255 & 27665 & & & & \\
\hline & & 2017 [29] & 19969 & 28107 & 3.71 & 1.60 & & \\
\hline
\end{tabular}

Table 2. Types of bitumen used on test sections

\begin{tabular}{|c|c|c|c|c|c|}
\hline Bitumen types & Bitumen mark & $\begin{array}{l}\text { Rubber content in asphalt mixture } \\
\qquad \%[\mathrm{~m} / \mathrm{m}]\end{array}$ & Sections & Positions & $\begin{array}{c}\text { Chainages } \\
{[\mathrm{km}]}\end{array}$ \\
\hline \multirow{3}{*}{$\begin{array}{l}\text { Traditional bitumen } \\
\text { B 50/70 }\end{array}$} & \multirow{3}{*}{$B-R$} & 1.0 & I & 1. & $0+160$ \\
\hline & & 1.0 & III & 5. & $116+750$ \\
\hline & & 1.1 & II & 4. & $20+950$ \\
\hline \multirow{4}{*}{$\begin{array}{l}\text { Polymer modified bitumen } \\
\text { PmB 50-90s }\end{array}$} & \multirow{2}{*}{ PmB-R } & 0.36 & III & 6. & $117+400$ \\
\hline & & 0.37 & II & 2. & $15+920$ \\
\hline & \multirow{2}{*}{ PmB } & \multirow{2}{*}{0.0} & ॥ & 3. & $15+820$ \\
\hline & & & III & 7. & $117+600$ \\
\hline
\end{tabular}

out on the use of waste car tire as a bitumen additive in order to achieve better properties of bituminous mixtures and to replace or reduce the proportion of polymers in bituminous binder. After laboratory research, three test sections of the SMA 8 and SMA 16 asphalt pavement with rubber were placed. The first test section (I) was realised on a city road in Zagreb, in the area of $6630 \mathrm{~m}^{2}$, the second test section (II) along the Zagreb motorway, in the area of $11550 \mathrm{~m}^{2}$, and the third test section (III) was realised on the Zagreb-Lipovac motorway (M3 motorway) in the area of $22500 \mathrm{~m}^{2}$. The traditional bitumen $\mathrm{B}$ 50/70 and polymer-modified bitumen PmB 50-90s were used as asphalt binder, and Asaplex F-100 rubber recycled granules were used as bitumen additive.

The aim of the test sections was to determine the advantages of using asphalt with rubber modified bitumen, i.e. to determine technical and economic benefits of asphalt with waste tire, and societal benefits of ensuring an environmentally-friendly disposal of waste tires.

For the purposes of the research, appropriate traffic load data were collected in the observed time period. Traffic load data were not taken into account for the reference test section I, because of the small size of this road section. Traffic count data for the period between 2008 and 2015 are available on the Jankomir and Lučko intersections in the test section II, where an average annual daily traffic (AADT) increased by $0.18 \%$, and average summer daily traffic (ASDT) by $9.13 \%$, as shown in Table 1. According to traffic load data measured in the period from 2006 to 2016 on the test section III, situated on the motorway M3 Zagreb-Lipovac (intersection Kutina - intersection Novska), the average annual daily traffic (AADT) increased by $18.71 \%$, and the average summer daily traffic (ASDT) by $16.15 \%$, as shown in Table 1. In the period from 2016 to 2017 , the AADT increased by $3.71 \%$, and ASDT by $1.60 \%$.

\section{Asphalt with and without rubber modified bitumen before exploitation in 2006}

\subsection{Materials for the production of asphalt mixtures}

The "Ljubeščica" stone materials 0/2, 2/4, 4/8 and 8/11 mm and "Očura" stone filler were used [30] for the production of asphalt mixtures. The quality control of materials and all required work were carried out in accordance with General Technical Requirements for Road Works [31]. Bitumen types shown in Table 2 were used for the production of SMA asphalt mixtures with modified rubber bitumen used on the test asphalt sections. Asaplex F-100 type recycled rubber granules were added to the bitumen mixture.

\subsection{Composition and properties of laboratory samples taken from bituminous mixtures}

The composition of bituminous mixtures with a bitumen content of 5.6 to $6.6 \%(\mathrm{~m} / \mathrm{m})$, determined during laying of mixtures on test sections, is shown in Table 3. The bitumen content was tested according to HRN EN 12697-1 [32]. The values given in Table 3 show mean values of examined samples (grading of crumb rubber in the range from 0 to $0,5 \mathrm{~mm}$ ) and void content 
Table 3. Composition of produced asphalt mixture and the air content in Marshall samples

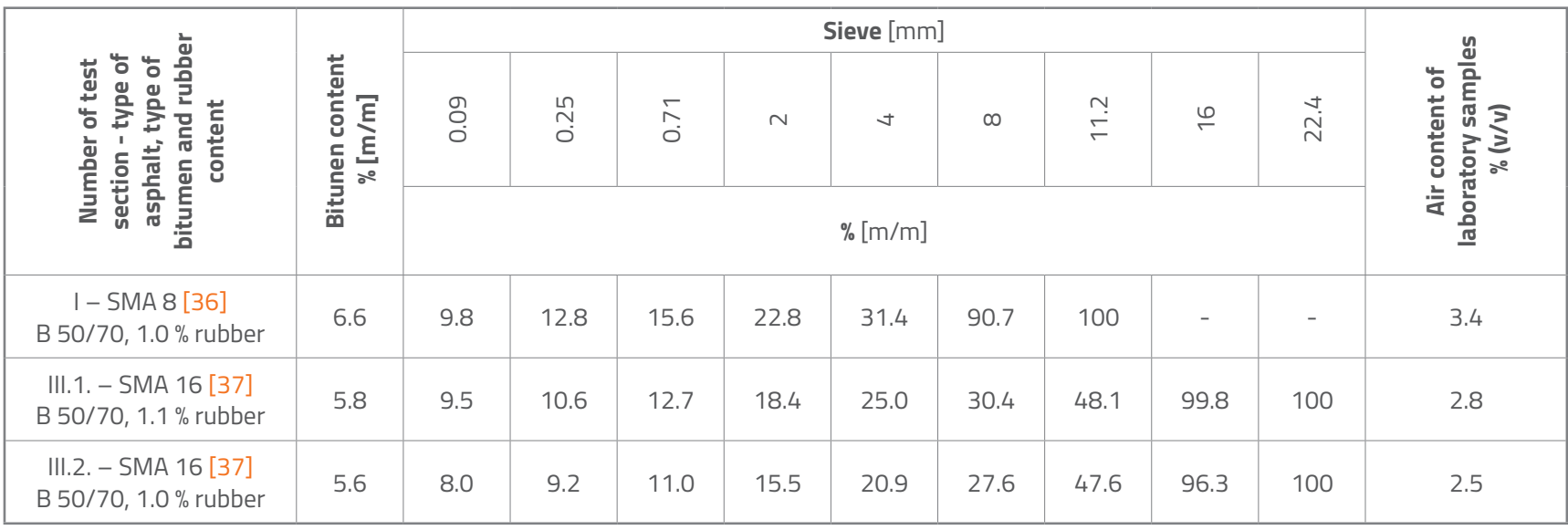

Table 4. Air content and degree of compactness in the layer and rutting resistance

\begin{tabular}{|c|c|c|c|c|c|}
\hline $\begin{array}{c}\text { Number of } \\
\text { section and type } \\
\text { of asphalt }\end{array}$ & $\begin{array}{c}\text { Air content in the layer / } \\
\text { quality condition } \\
{[\%]}\end{array}$ & $\begin{array}{c}\text { Degree of compactness } \\
\text { / quality condition } \\
{[\%]}\end{array}$ & $\begin{array}{c}\text { Layer thickness / design } \\
\text { thickness } \\
{[\mathrm{mm}]}\end{array}$ & $\begin{array}{c}\text { WTS bitumen } \\
\text { content / PRD } \\
\%[\mathrm{~m} / \mathrm{m}]\end{array}$ & $\begin{array}{c}\text { Density layer } \\
{\left[\mathrm{Mg} / \mathrm{m}^{3}\right]}\end{array}$ \\
\hline I- SMA 8 & $7.4 / 2.5-8$ & $99.2 / \geq 98$ & $41.9 / 30$ & $6.6 / 5.6$ & 2.353 \\
\hline III.1. - SMA 16 & $4.0 \% / 2.5-8$ & - & - & $5.8 / 4.9$ & 2.463 \\
\hline III.2. - SMA 16 & $5.5 \% / 2.5-8$ & - & - & $5.6 / 3.3$ & 2.436 \\
\hline
\end{tabular}

of Marshall samples prepared according to HRN EN 12697-30 [33].

The density of the produced bituminous mixture was determined [34], and the asphalt density was determined according to HRN EN 12697-6 [35] on Marshall samples made in the laboratory. The air content was calculated according to HRN EN 12697-8 [36].

Marshall asphalt samples were tested for stability and deformation. The stiffness $(\mathrm{kN} / \mathrm{mm})$ was calculated from the relationship between stability (kN) and deformation (mm), as shown in Figure 1.

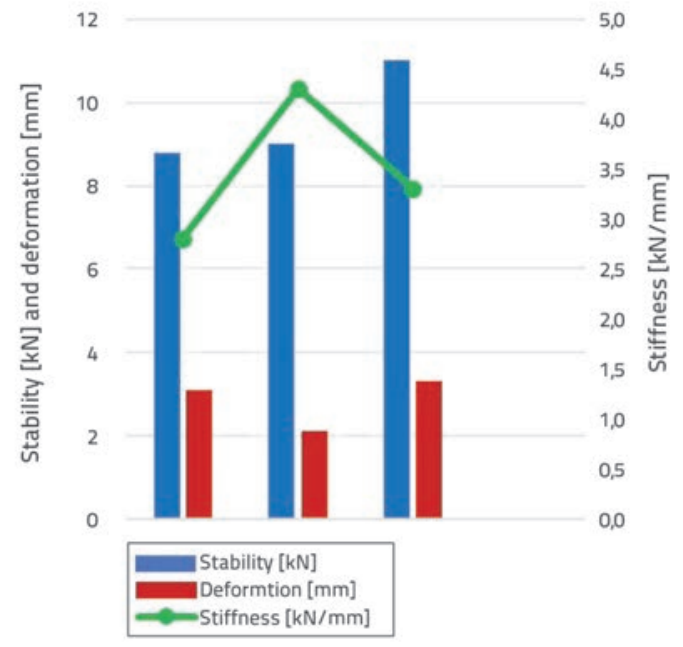

Figure 1. The relationship of stability (kN), deformation $(\mathrm{mm})$ and stiffness $(\mathrm{kN} / \mathrm{mm})$

\subsection{Properties of the produced asphalt layer before exploitation}

After the applied asphalt layer was tested on samples taken from pavement test sections, the layer density and thickness were determined according to HRN EN 12697-5 [34] and HRN EN 12697-36 [39], respectively. The air content in the layer was tested according to HRN EN 12697-8 [36] and the degree of compactness was determined. The corresponding test results are shown in Table 4.

The rutting was tested on asphalt samples along longitudinal path in the wheel with slight elevations at the edges. The samples were subjected to progressive deformations at repeated loads of the test wheel. The highest WTS $_{\text {AIR }}$ speed rutting and the highest $\mathrm{PRD}_{\text {AIR }}$ relative depth rutting were tested according to HRN EN 12697-22 [40]. At the first test section (I), the highest WTS $_{\text {AIR }}$ rate is 0.02 (mm/1000 cycles), and the highest relative depth of $\mathrm{PRD}_{\mathrm{AIR}}$ is $5.6 \%$. On the III test section, the rutting speed varies from the highest of 0.042 (mm/1000 cycles) to the 5 th position, to a minimum of 0.023 (mm/1000 cycles) in the 6th position. Relative depth of ruts ranges from $3.3 \%$ to $4.9 \%$. It can be noticed that the same relative depth of rut was obtained in the position of asphalt with rubber and in the position without rubber.

The skid resistance was investigated according to HRN EN 13036-4 [41] on pavement surface, as shown in Figure 2 (Section III).

Results of pavement surface depth testing according to HRN EN 13036-1 [42] are shown in Figure 3. 


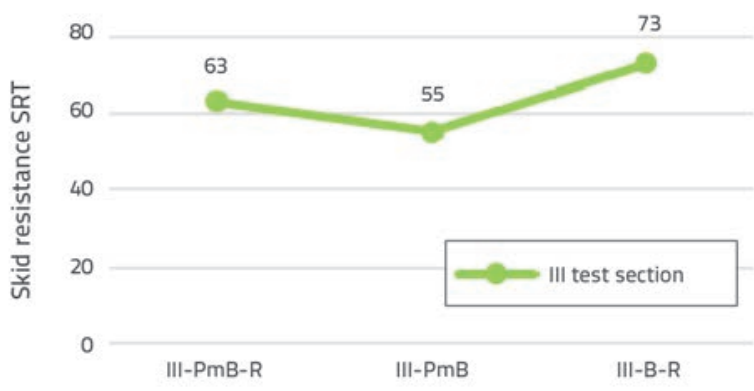

Figure 2. Skid resistance on pavement surface

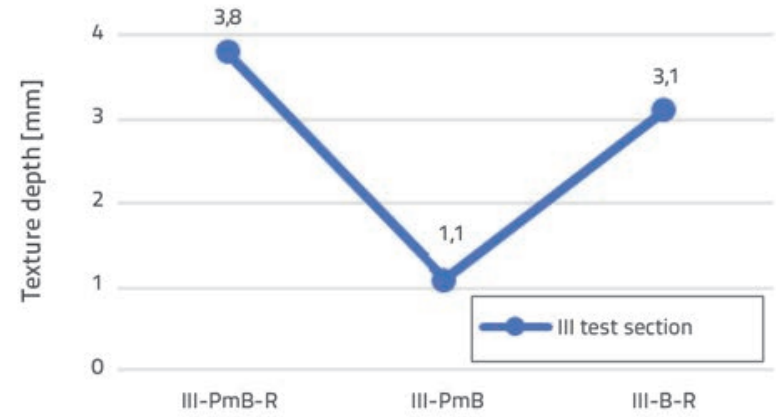

Figure 3. Texture of pavement surface

The state of pavement is measured by defining longitudinal roughness of the pavement surface. To obtain an objective picture about the roughness and driving comfort, it is necessary to carry out measurements using the state of the art measuring devices. The longitudinal roughness was tested by electronic "Walking Profile" according to AGPT/ T450 [43] and HRN EN 13036-5 [44], and the International Roughness Index amounted to IRI $=1.59 \mathrm{~m} / \mathrm{km}$ on one traffic lane, while it was $|R|=1.72 \mathrm{~m} / \mathrm{km}$ on the other traffic lane. The total mean value of the longitudinal roughness index was $\mathrm{IRI}=1.66 \mathrm{~m} / \mathrm{km}$.

\section{Asphalt with rubber modified bitumen after exploitation in the period $2006-2017$}

\subsection{Sampling and measurements of asphalt on test sections}

After 11 years of service under traffic load as shown in Table 1 , investigations were carried out on the asphalt pavement with rubber and polymer modified bitumen to determine asphalt layer and pavement surface properties at seven positions on three test sections (Table 2):

- on the first test section (I): asphalt SMA 8 [45] with the addition of rubber, in one position;

- on the second test section (II): asphalt HS 16D (SMA), in three positions, at one position asphalt without the addition of rubber $(\mathrm{PmB})_{i}$

- on the third test section (III): asphalt HS 16D (SMA-EN) [45], in three positions - at one position asphalt without the addition of rubber (PmB).
Asphalt sampling and measurements were carried out by Ramtech Ltd. All tests were conducted in Ramtech Ltd. laboratory.

At the request of the Zagreb University of Applied Sciences, Construction Department, the consent of the Zagreb City Office was obtained before the asphalt pavement sampling at test section I., and a similar approval of Croatian Motorways was obtained for test sections II and III, so that a temporary regulation of traffic can be established. The temporary traffic control at test section I was set up by means of a vehicle with a lighting arrow that informed drivers which traffic lanes were temporarily closed to traffic. At test sections II and III, temporary traffic control was set up by means of the joints and the arrows in such a way that the traffic flowed through the acceleration lane. A vehicle queue more that 4 kilometres long was formed although the sampling time was coordinated with the competent traffic services at the $2^{\text {nd }}$ test section run (between 10 and 12 a.m., out of the daily, weekly and seasonal peak traffic flows). Temporary traffic regulation had to be set so that asphalt sampling and measuring could safely be carried out without any risk to work staff. An additional lighted arrow was placed at the exit of the rest area (Ra Lipovljani) at test section III so that vehicles leaving the parking lot were properly advised about the sampling.

\subsection{Test section I - Sveučilišna Avenue in the City of Zagreb}

At test section I, samples were taken in the summer of 2017, in the north-south direction, on the right side traffic lane, at chainage $\mathrm{km} 0+160$. The sampling weather was sunny, hot and wind-free, with a $33^{\circ} \mathrm{C}$ air temperature. Asphalt pavement samples measuring $3 \times \emptyset 200 \mathrm{~mm}$ and $8 \times \varnothing 100 \mathrm{~mm}$ (Figure 4) were drilled in the scope of the sampling procedure. The asphalt layer of split mastic asphalt SMA 8 with bituminous binder bitumen B 50/70 was tested, and the waste rubber content was $1.0 \%$. A recycled Asaplex F100 type tire (low temperature tire based mainly on natural rubber) was used in the testing.

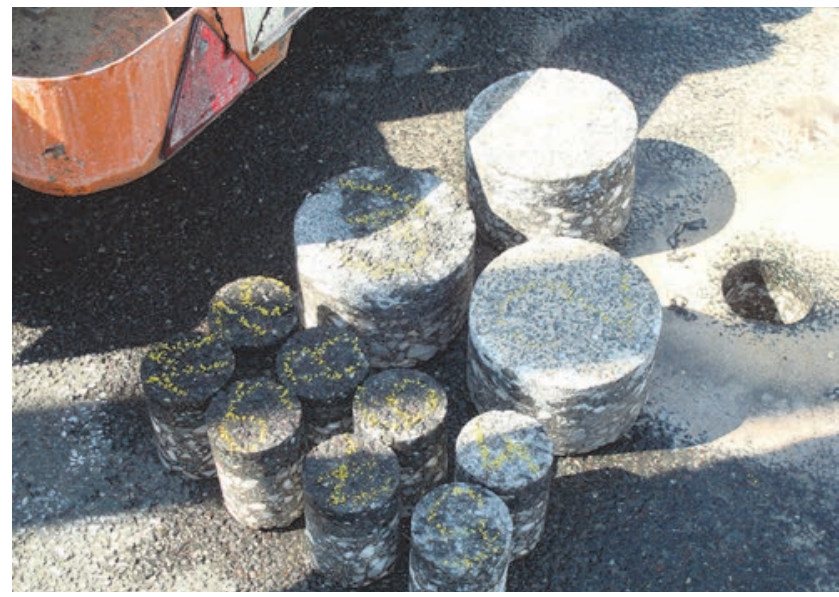

Figure 4. An overview of all eleven drilled samples 
On the pavement surface, the skid resistance was tested by the Skid Resistance Tester according to HRN EN 13036-4 [41]. The corresponding results are shown in Table 13. The texture of the road surface was determined by sandblasting according to HRN EN 13036-1 [42]. After the sampling, a visual inspection of the section was made, and micro (proprietary) cracks were observed. The wear of the driving surface was noted near the wheel of a parked vehicle (Figure 5). Grid cracks were noted near the manhole cover and longitudinal and transverse cracks were registered in the centre of the traffic lane.

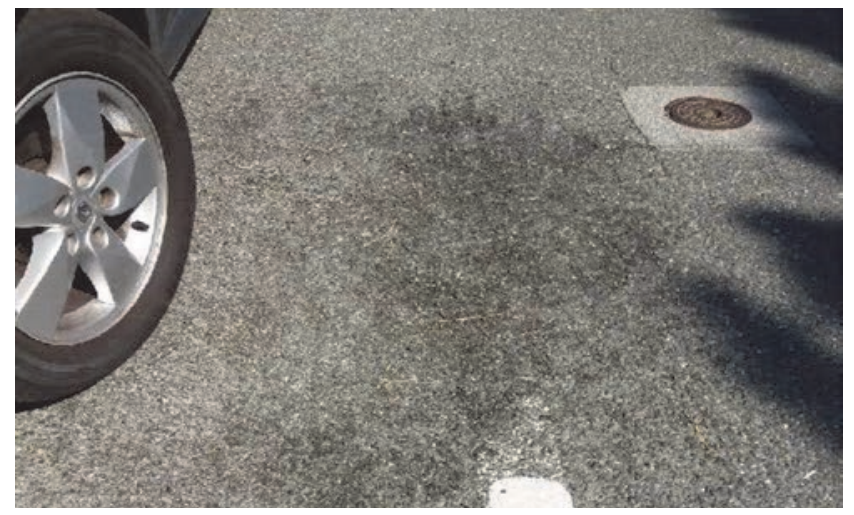

Figure 5. Detail of driving surface wear

\subsection{Test section II - Zagreb bypass}

The sampling campaign was conducted in the autumn of 2017 on the northbound traffic lane of the Motorway Bypass, in the Zagreb - Bregana direction (to the border with Slovenia). The sampling weather was cold with a temperature of about $10^{\circ} \mathrm{C}$. The three test positions are situated at the following chainages: $\mathrm{km}$

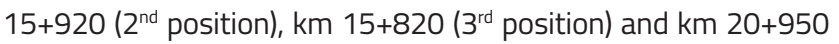
( $4^{\text {th }}$ position), all in the centre of the traffic lane. A cracking with a recess (structural problem regarding pavement construction) was observed by visual examination on the $2^{\text {nd }}$ test section.

\subsection{Test section III - Motorway A3/M3 Zagreb- Lipovac (Lipovljani-Dragalic)}

Samples were taken on test section III in the autumn of 2017, during cloudy weather at moderate temperature. The three asphalt pavement test positions are situated at the following chainages: $\mathrm{km} 116+750 \quad\left(5^{\text {th }}\right.$ position), $\mathrm{km} 117+400 \quad\left(6^{\text {th }}\right.$ position) and $\mathrm{km} 117+600$ ( $7^{\text {th }}$ position) all in the traffic lane. On this section, visual inspection revealed cracking at the contact between rubber asphalt and asphalt without rubber. Cracks are not filled, which allows penetration of water into the pavement and its degradation.

\section{Bitumen properties tested on asphalt test sections after 11 years of service}

The aim of the test sections is to determine advantages of using asphalt with rubber modified bitumen, i.e. to establish technical and economic benefits of asphalt with rubber addition, and for ecological disposal of waste tires. The positions on each experimental test section contain various types of binder used during initial pavement construction in 2006. Rubber was used as additive to asphalt at some of these positions. All seven asphalt layer types were studied and tested at these positions. Due to the presence of rubber in the asphalt, the following three binder types were used:

- B-R, traditional bitumen B 50/70 with $1 \%$ Asaplex F-100

- PmB-R, polymer modified bitumen PmB 50-90s with $0.3 \%$ Asaplex F-100

- PmB, polymer modified bitumen Pmb 50-90s without addition.

Table 5 shows results obtained by testing softening point (ring\&ball) properties, penetration, and elastic return of bitumen at test sections under study, according to rubber content.

If the mutually separated binder after 11 years, $P m B-R$, is compared to the asphalt with the addition of rubber and $\mathrm{PmB}$

Table 5. An overview of softening point, penetration and elastic return of bitumen

\begin{tabular}{|c|c|c|c|c|}
\hline \multirow{2}{*}{$\begin{array}{l}\text { Number of test section and } \\
\text { bitumen mark }\end{array}$} & \multirow{2}{*}{$\begin{array}{l}\text { Rubber content in asphalt } \\
\text { mixture } \\
{[\%]}\end{array}$} & \multicolumn{3}{|c|}{ Binder characteristics extracted from asphalt layers positions } \\
\hline & & $\begin{array}{l}\text { Softening point } \\
\operatorname{PK}\left[{ }^{\circ} \mathrm{C}\right]\end{array}$ & $\begin{array}{l}\text { Penetration } \\
(1 / 10 \mathrm{~mm})\end{array}$ & $\begin{array}{c}\text { Elastic return } \\
{[\%]}\end{array}$ \\
\hline I-B-R & 1.0 & 65.4 & 37 & 50 \\
\hline II-PmB-R & 0.3 & 69.2 & 52 & 89 \\
\hline II-PmB & 0.0 & 70.8 & 36.6 & 85 \\
\hline II-B-R & 1.0 & 57.5 & 38 & 46 \\
\hline III-PmB-R & 0.3 & 71.4 & 40 & 80 \\
\hline III-PmB & 0.0 & 66.1 & 39.1 & 80 \\
\hline III-B-R & 1.0 & 52.2 & 53.2 & 36 \\
\hline
\end{tabular}


Table 6. Grading of bituminous mixtures extracted from asphalt pavement

\begin{tabular}{|c|c|c|c|c|c|c|c|c|c|c|}
\hline \multirow{2}{*}{$\begin{array}{c}\text { Section and } \\
\text { bitumen mark }\end{array}$} & \multirow{2}{*}{$\begin{array}{c}\text { Bitumen content } \\
{[\%]}\end{array}$} & \multicolumn{9}{|c|}{ Grading [\%] according to EN 933-1 [46] with sieve sizes according to EN 933-2 [47] [mm] } \\
\hline & & 0.063 & 0.25 & 1 & 2 & 4 & 8 & 11.2 & 16 & 22.4 \\
\hline I-B-R & 7.6 & 11.0 & 12 & 17 & 24 & 36 & 95 & 100 & 100 & 100 \\
\hline II-PmB-R & 5.8 & 8.4 & 12 & 19 & 24 & 33 & 49 & 70 & 100 & 100 \\
\hline II-PmB & 6.3 & 7.8 & 12 & 19 & 25 & 35 & 57 & 74 & 99 & 100 \\
\hline II-B-R & 6.2 & 8.4 & 10 & 17 & 22 & 32 & 48 & 70 & 96 & 100 \\
\hline III-PmB-R & 5.7 & 9.1 & 11 & 17 & 22 & 27 & 33 & 60 & 100 & 100 \\
\hline III-PmB & 5.4 & 10.6 & 15 & 20 & 24 & 30 & 39 & 63 & 98 & 100 \\
\hline III-B-R & 6.2 & 10 & 11 & 17 & 24 & 29 & 36 & 59 & 100 & 100 \\
\hline
\end{tabular}

without the addition of rubber, it becomes apparent that the properties are approximately the same, except that the penetration increases with $\mathrm{PmB}-\mathrm{R}$. It can therefore be concluded that $0.3 \%$ of rubber in the asphalt after 11 years reduces hardening of polymer bitumen, although the binder remains equally degraded and exhibits the same elastic properties as the $\mathrm{PmB}$ without rubber after 11 years.

The results for traditional bitumen extracted after 11 years from the asphalt with the addition of rubber show that $1 \%$ of rubber in the asphalt polymerized. This is particularly evident from the elastic return characteristic, which appears in the binder at all three sections. The impact of the tire is most visible at the test section I, where highest values of softening point and elastic return were registered.

If bitumen properties obtained in service are compared, the following can be concluded by comparison between the traditional bitumen B 50/70 with the rubber (B-R) and the polymer modified bitumen PmB 50-90s with rubber (PmB-R) and without rubber $(\mathrm{PmB})$ :

- traditional bitumen B 50/70 with $1 \%$ of the rubber, becomes, after 11 years of service, a binder that is classified as a harder type of polymer bitumen B 25/55-55;

- polymer bitumen PmB degraded and oxidised after 11 years of pavement use, but it has still retained essential elastic properties typical for binders;

- polymer bitumen PmB-R extracted from asphalt, with 0,3\% of rubber, exhibits a reduced hardness, i.e. its hardness has reduced to the level of $\mathrm{PmB}$ without the addition of rubber, while other properties have remained approximately equal and without major differences.

\section{Results of tests and measurements on asphalt test sections after 11 years of service}

Results obtained on the asphalt wearing course after eleven years of service (2006 - 2017) were analysed by comparing the mixture of the same composition with different types of bituminous binders ( $B-R$ and $P m B-R$ ), with and without rubber additive $(\mathrm{PmB})$. The alteration made by adding rubber bitumen binder to asphalt properties was taken into account.
Comparisons were made within one part of the asphalt (same composition, different binder) and between the asphalts of the two test sections, II and III (different composition, same binder).

\subsection{Composition of bituminous mixtures}

\subsubsection{Grading of bituminous mixture}

The grading is characterized by three different types of split mastic asphalt (SMA). It is a mixture of SMA 8 with $8 \mathrm{~mm}$ nominal grain size (test section I) and two nominal grain sizes of $16 \mathrm{~mm}$ (test sections II and III) but with the different maximum grain size. The bituminous mixture SMA 16 (grading according to EN standard) at test section II contains about $30 \%$ of 11/16 mm aggregate fraction, while the SMA 16 mix from test section III has a grading with approximately $40 \%$ of the same fraction (Table 6).

\subsubsection{Volumetric composition of bituminous mixture}

Cores were extracted from the wearing asphalt course of the pavement, and samples were prepared and tested in the laboratory. Volumetric characteristics of samples were determined according to HRN EN 12697-6 [35], as shown in Table 7.

\subsubsection{Volumetric composition of asphalt layer}

The degree of compactness of asphalt layers has been calculated according to laboratory test results, using samples extracted from pavement. It was concluded that all asphalt layers have passed an appropriate process of additional compression, and are installed at their maximum compaction levels (Table 8). These data are important for understanding rutting resistance results.

\subsection{Stability and stiffness of Marshall's samples of bituminous mixtures}

The stability and stiffness of Marshall's samples $101.6 \mathrm{~mm}$ diameter prepared with Marshall Device according to EN 
Table 7. Volumetric composition of bituminous mixtures extracted from pavement

\begin{tabular}{|c|c|c|c|c|c|}
\hline $\begin{array}{c}\text { Section and } \\
\text { bitumen mark }\end{array}$ & $\begin{array}{c}\text { Bitumen } \\
\text { content } \\
\%(\mathbf{m} / \mathbf{m})\end{array}$ & $\begin{array}{c}\text { Mixture } \\
\text { density } \\
{\left[\mathrm{Mg} / \mathrm{m}^{3}\right]}\end{array}$ & $\begin{array}{c}\text { Density of the } \\
\text { laboratory sample } \\
{\left[\mathrm{Mg} / \mathrm{m}^{3}\right]}\end{array}$ & $\begin{array}{c}\text { Air content of the } \\
\text { laboratory sample } \\
\%(\mathrm{v} / \mathrm{v})\end{array}$ & $\begin{array}{c}\text { Bitumen air content in stone } \\
\text { material } \\
\%(\mathrm{v} / \mathrm{v})\end{array}$ \\
\hline I-B-R & 7.6 & 2.477 & 2.393 & 3.4 & 84.0 \\
\hline II-PmB-R & 5.8 & 2.575 & 2.491 & 3.3 & 81.2 \\
\hline II-PmB & 6.3 & 2.617 & 2.543 & 2.8 & 84.6 \\
\hline II-B-R & 6.2 & 2.570 & 2.471 & 3.9 & 79.3 \\
\hline III-PmB-R & 5.7 & 2.568 & 2.504 & 2.5 & 84.9 \\
\hline III-PmB & 5.4 & 2.632 & 2.531 & 3.8 & 77.8 \\
\hline III-B-R & 6.2 & 2.552 & 2.481 & 2.8 & 84.6 \\
\hline
\end{tabular}

Table 8. Elements of the asphalt layer volumetric composition

\begin{tabular}{|c|c|c|c|c|}
\hline Section and bitumen mark & $\begin{array}{c}\text { Layer thickness } \\
{[\mathrm{mm}]}\end{array}$ & $\begin{array}{c}\text { Layer density } \\
{\left[\mathrm{Mg} / \mathrm{m}^{3}\right]}\end{array}$ & $\begin{array}{c}\text { Air content in layer } \\
{[\%]}\end{array}$ & $\begin{array}{c}\text { Layer compactness degree } \\
{[\%]}\end{array}$ \\
\hline I-B-R & 42 & 2.390 & 3.5 & 99.9 \\
\hline II-PmB-R & 53 & 2.515 & 2.3 & 101.0 \\
\hline II-PmB & 46 & 2.562 & 2.1 & 100.7 \\
\hline II-B-R & 49 & 2.472 & 3.8 & 100.1 \\
\hline III-PmB-R & 54 & 2.505 & 2.5 & 100.0 \\
\hline III-PmB & 54 & 2.525 & 4.1 & 99.7 \\
\hline III-B-R & 55 & 2.498 & 2.1 & 100.7 \\
\hline
\end{tabular}

Table 9. Stability and stiffness of laboratory samples

\begin{tabular}{|c|c|c|c|c|c|c|c|c|}
\hline Properties & Unit & I-B-R & II-PmB-R & II-PmB & II-B-R & III-PmB-R & III-PmB & III-B-R \\
\hline Stability S & kN & 11.6 & 10.8 & 9.4 & 10.2 & 10.8 & 11.4 & 11.3 \\
\hline Deformation d & $\mathrm{mm}$ & 4.6 & 6 & 3.9 & 5.5 & 5.2 & 6.6 & 5.2 \\
\hline Stiffness S/d & $\mathrm{kN} / \mathrm{mm}$ & 2.5 & 1.8 & 2.4 & 1.8 & 2.1 & 1.7 & 2.2 \\
\hline
\end{tabular}

12697-34 [48] were tested at a temperature of $60^{\circ} \mathrm{C}$. There is no clear trend in the values of stability and stiffness in asphalt of the same composition and different binders, and no irregularity was observed with asphalt of the same binder and different composition (Table 9).

The differences that appear between them do not point to a certain regularity regarding asphalt composition or type of binder. The same can be concluded for calculated stiffness, while a higher stiffness in the polymer modified bitumen with the addition of rubber (III-PmB-R) was determined for bituminous mixtures prior to exploitation (Figure 1).

\subsection{Water sensitivity}

Water sensitivity is one of main mechanisms leading to the damage and decay of asphalt. It is characterized by the loss of adhesive connection between the bituminous binder and the aggregate, and by the weakening of cohesive connection within the bitumen binder due to traffic load and presence of moisture. The asphalt resistance to water activity was tested on samples prepared with reduced compaction energy in laboratory. Reduced compression energy assumes the case of a poorly installed asphalt layer with air content at the upper limit of acceptability. These preparation conditions are suitable for assessing usability of asphalt barely meeting asphalt layer placing requirements, and so the minimum compression and maximum air content values are checked as indicated in HRN EN 12697-12 [49].

Asphalt sensitivity to water performance was tested according to HRN EN 12697-12 [49]. 101,6 mm cylindrical samples were prepared from asphalt mixes using the Marshall device with $2 \mathrm{x}$ 35 impact force. The reference sample group (ITSdry) was kept at dry room temperature of $25^{\circ} \mathrm{C}$, while the water saturated group (ITSwet) was conditioned in a water bath at $40^{\circ} \mathrm{C}$. After three days of conditioning, both test groups were subjected to indirect tensile strength testing (HRN EN 12697-23) [50] at test temperature of $15^{\circ} \mathrm{C}$. The difference between the indirect tensile strength of the conditioned water test group and the air 
Table 10. Water sensitivity of laboratory sample made of asphalt mixture

\begin{tabular}{|c|c|c|c|c|c|c|c|c|}
\hline Properties & Unit & I-B-R & II-PmB-R & II-PmB & II-B-R & III-PmB-R & III-PmB & III-B-R \\
\hline ITS $_{\text {wet }}$ & $\mathrm{kPa}$ & 1420 & 1170 & 1370 & 1870 & 1040 & 1210 & 1710 \\
\hline ITS $_{\text {dry }}$ & $\mathrm{kPa}$ & 1590 & 1550 & 2180 & 2440 & 1220 & 1920 & 2040 \\
\hline ITSR & $\%$ & 89.3 & 75.5 & 62.8 & 76.6 & 85.2 & 63.0 & 83.8 \\
\hline
\end{tabular}

Table 11. Resistance to rutting or permanent deformation of asphalt samples

\begin{tabular}{|c|c|c|c|c|c|c|c|c|}
\hline Properties & Unit & I-B-R & II-PmB-R & II-PmB & II-B-R & III-PmB-R & III-PmB & III-B-R \\
\hline WTS & AIR & mm/1000 cycles & 0.06 & 0.09 & 0.07 & 0.12 & 0.06 & 0.04 \\
\hline PRD $_{\text {AIR }}$ & $\%$ & 2.1 & 3.7 & 3.3 & 5.0 & 3.9 & 2.3 \\
\hline
\end{tabular}

conditioned test group was determined. Each group contained three samples, and the mean values of the reference tensile strength (ITSdry) and wet tensile strength (ITSwet), as well as their ratios (ITSR), are listed in Table 10.

Both SMA 16 mixtures (grading according to EN standard) on test section II, and SMA 16 on test section III, with both types of rubber binder, polymer modified $\mathrm{PmB}-\mathrm{R}$, and traditional B-R bitumen, exhibit a significantly greater ability to resist degradation by water action, compared to polymer bitumen PmB without rubber. Water sensitivity of ITSR asphalt with PmB-R and B-R rubber is similar, with a negligible difference. Asphalt with bitumen without rubber is $10 \%$ less resistant to SMA 16 (grading according to EN standard) and $21 \%$ less resistant to SMA 16 compared to asphalt binder with rubber. Resistance to the ITSR of all rubber asphalt is higher on test section III, whereas the opposite is true for pure PmB without rubber.

Indirectly measured tensile strength of dry ITSdry and wet ITSwet group samples are within each section are the smallest for the PmB-R binder, and the largest for B-R. The tensile strength of the dry and wet groups of test section II is higher than that of test section III.

It can be concluded that SMA 16 (grading according to EN standard) of finer grading has better tolerance to load but a lower water resistance. This is due to the possible effect of different types of aggregates in the asphalt mixtures of two sections since it exerts a significant influence on the bitumen film adhesion ability.

\subsection{Resistance to rutting}

Resistance to rutting was tested on original $200 \mathrm{~mm}$ diameter samples extracted from the pavement. Sample preparation and testing were carried out on a small device in the air according to process B presented in EN 12697-22 [40]. Before and during the test, the device and test samples were conditioned at $60^{\circ} \mathrm{C}$, and the load was set to 10,000 cycles or 20,000 transitions of the standardly loaded rubber wheel. Two parameters describing resistance to permanent deformation of the asphalt layer are the WTS $_{A R}$ coefficient of velocity expressed in millimetres of deformation generated at every 1000 cycles, and the largest relative deformation $\mathrm{PRD}_{A R^{\prime}}$ which is the percentage ratio of the deepest depth to the thickness of the layer in the test.

The best resistance to permanent deformation, i.e. the smallest rutting speed as well as relative deformation, has been achieved for asphalt with PmB binder (Table 11). The result for PmB-R binder is slightly worse, with a higher speed and higher relative deformation compared to asphalt with PmB binder without rubber. The weakest resistance to rutting is exhibited by asphalt $B-R$ which suffered the greatest relative deformation and speed of rutting. All exhibited applies to asphalt SMA 16 (EN) test section II and SMA 16 test section III.

By comparing test sections II and III, it can be seen that the speed of rutting is generally lower at test section III, which is positive and is not surprising given the larger asphalt grading. Comparing the greatest deformation at two test sections, i.e. SMA 16 (grading according to EN standard) with finer grading, and SMA 16 with coarser grading, it is clear that asphalt with rubber, II-PmB-R and II-BR, exhibits a lower relative deformation than the asphalt with rubber III-PmB -R and III-BR. Conversely, II-PmB exhibits a greater deformation than III-PmB.

Since the compactness of all asphalt layers tested is equal to the maximum, it can be concluded that the binder or bitumen mortar exhibits the dominant influence on the resistance to the rutting, and that the consistency of such binder is influenced by elevated temperatures. Since the penetration, elasticity and softening point of binders II-PmB-R and III-PmB-R extracted from rutted asphalt is higher than the combination of binder without rubber, i.e. II-PmB and III-PmB, this could explain the poorer resistance to rutting of asphalt with rubber compared to asphalt without rubber. It is a likely consequence of the more pronounced ageing (oxidation) of the binder in asphalt without the addition of rubber.

\subsection{Stiffness modulus}

The stiffness modulus of asphalt layer was tested according to EN 12697-26 [51], Appendix C (IT-CY), by an indirect tensile procedure on cylindrical samples $100 \mathrm{~mm}$ in diameter originating from the observed road construction. It represents the ratio of 
Table 12. Stiffness of asphalt samples from the layer

\begin{tabular}{|c|c|c|c|c|c|c|c|}
\hline Properties & Unit & II-PmB-R & II-PmB & II-B-R & III-PmB-R & III-PmB & III-B-R \\
\hline Stiffness modulus, $\mathrm{S} 20^{\circ} \mathrm{C}$ & $\mathrm{MPa}$ & 1479.7 & 2106.0 & 4726.3 & 1894.3 & 3748.7 & 3670.0 \\
\hline
\end{tabular}

Table 13. Skid resistance of asphalt layers

\begin{tabular}{|c|c|c|c|c|c|c|c|}
\hline Properties & Unit & I-B-R & II-PmB-R & II-PmB & II-B-R & III-PmB-R & III-PmB \\
\hline Skid resistance & SRT & - & 58 & 53 & 52 & 56 & 56 \\
\hline
\end{tabular}

the load to resulting deformation, and serves as a measure of structural stability of asphalt layers in road construction. The test was carried out at a temperature of $20^{\circ} \mathrm{C}$, according to the frequency prescribed by the standard.

According to rutting results, the asphalt stiffness of the PmB-R binder is expected to be less than that of the pure polymeric bituminous PmB, as shown in Table 12. However, contrary to expectations, the stiffness of the $\mathrm{B}-\mathrm{R}$ binder is the greatest despite the fact that this asphalt exhibited the greatest permanent deformation during the rutting resistance test. The cause can be attributed to different test temperatures of two methods, i.e. the stiffness can be classified as a medium increasing property and the resistance to permanent deformation at higher temperatures of use. It has been confirmed that the stiffness and the indirect tensile strength are followed by the same trend of increase from the measured smallest PmB-R binder combination to the maximum B-R combination of traditional bitumen with rubber.

Test section III has the lowest stiffness at asphalt PmB-R, while stiffness values are almost equal for asphalts $\mathrm{PmB}$ and $\mathrm{B}-\mathrm{R}$.

By comparing two sets of results for sections II and III, it can be seen that there is a certain inconsistency in the trend of increase in stiffness values of asphalts PmB-R to $B-R$. It is assumed that this causes dispersion of measured results.

\subsection{Skid resistance of asphalt pavement at test sections after 11 years of service}

The skid resistance was tested by a pendulum (pendulum tester) according to EN 13036-4 [41]. The skid resistance results confirm that the addition of rubber to bitumen binder increases skid resistance of asphalt pavement (Table 13). It can also be observed that the texture of SMA 16 at test section III reveals better average skid resistance.

It should be noted that previously known skid resistance values were mainly measured immediately after placement, while the asphalt layer has not yet suffered traffic, and it is interesting to note that these values have changed after the asphalt layer has been subjected to long period of service. Of course, most of the bitumen mortar has disappeared from pavement surface due to traffic load, which is why the described results have been obtained (microtexture).

\section{Conclusion}

The research on the asphalt surfacing layer was performed after eleven years of exploitation (2006-2017) by comparing bituminous mixtures of the same composition with different types of bituminous binders with and without addition of recycled car tires. The following conclusions can be made based on the results of tests and measurements made on trial sections:

- there is no clear regularity in asphalt stability and rigidity with respect to the similarity of the bituminous mixtures composition or the same combination of bituminous binders, but these are mostly substitutions with dynamic tests of asphalt properties (rutting and stiffness);

- the addition of rubber to bituminous binder enhances asphalt resistance to detrimental effect of water;

- tensile strength of asphalt with polymer bitumen and rubber is lower compared to asphalt with polymer bitumen without rubber, while the highest tensile strength values were recorded for traditional bitumen with rubber;

- the addition of rubber granules to bituminous binder reduces resistance to rutting of asphalt that has undergone a long period of service, as a result of increased oxidation of bitumen without addition of rubber;

- asphalt stiffness of traditional bitumen with rubber is higher compared to polymer bitumen with rubber, which confirms the effect of tire addition together with polymer in bituminous binder, and reduction in asphalt cracking (asphalt with polymer bitumen without rubber has a greater stiffness than asphalt with polymer bitumen and rubber);

- the addition of recycled rubber to bitumen binder increases coefficient of friction at the asphalt pavement surface.

\section{REFERENCES}

[1] Zagvozda, M., Dimter, S., Dolaček-Alduk, Z.: Alternativni materijalinovi trend i izazov u graditeljstvu, Sabor hrvatskih graditelja 2012, Graditeljstvo - poluga razvoja (ur. Lakušić, S.), pp. 145-154, Cavtat 15.-17. studeni 2012., in Croatian.

[2] Aleksić, K.: Problemi i perspektive zbrinjavanja otpada u Republici Hrvatskoj, Diplomski rad, Sveučilište u Splitu, Ekonomski fakultet, Split, travanj 2017., in Croatian. 
[3] Lo Presti, D.: Recycled Tyre Rubber Modified Bitumen for road asphalt mixtures, Construction and Building Materials, 49 (2013), pp. 863-881

[4] Pravilnik o gospodarenju otpadnim gumama, NN 113/16, Hrvatski sabor, siječanj 2017.

[5] Hungarian Tyre Association, http://www.hta.org.hu/eng/tire.html, 25.7.2018.

[6] Kisgyörgy, L., Tózh, C., Geiger, A.: Elastic modulus of asphalt with chemically stabilized rubber bitumen, Građevinar, 68 (2016) 7, pp. 533-541, doi: https://doi.org/10.14256/JCE.1451.2015

[7] Serdar, M., Baričević, A., Lakušić, S., Bjegović, D.: Special purpose concrete products from waste tyre recyclates, Gradevinar, 65 (2013), 9, pp. 793-801

[8] Council of the European Union, "Council Directive 1999/31 EC of 26 April 1999 on the land fill of waste", 1999.

[9] Vrekić, S.: Prilog recikliranju materijala u auto industriji i ugrožavanje životne sredine,

[10] http://www.cqm.rs/2012/cd1/pdf/39/36.pdf, 2.8.2018.

[11] Palković, B.: Guma u asfaltu, Dani prometnica 2010, Nove tehnologije i materijali (ur. Lakušić, S.), Građevinski fakultet, Zagreb, veljača 2010., pp. 295-313, in Croatian.

[12] Zhang, F., Hu, C.: The research for structural characteristics and modification mechanism of crumb rubber compound modified asphalts, Construction and Building Materials, 76 (2015), pp. 330342

[13] Shen, J., Xie, Z.: Comprehensive evaluation of the long-term performance of rubberized pavement: Phase I: Laboratory study of rubberized asphalt mix performance (No. FHWA-GA-12-1119), 2012.

[14] Rahman, M.M., Airey, G D., Collop, A.C.: The mechanical properties of the dry process CRM asphalt mixtures following short-term and long-term ageing, Seventh International Conference on the Bearing Capacity of Roads, Railways and Airfields, Trondheim, Norway, 2005.

[15] Tai Nguyen, H.T., Nhan Tran, T.: Effects of crumb rubber content and curing time on the properties of asphalt concrete and stone mastic asphalt using dry process, International Journal of Pavement Research and Technology, 11 (2018), pp. 236-244

[16] Shen, J., Li, B., Zhaoxing, X.: Interaction between crumb rubber modifier (CRM) and asphalt binder in dry process, Construction and Building Materials, 149 (2017), pp. 202-206

[17] Choubane, B., Sholar, G., Musselman, J., Page, G.: Ten-year performance evaluation of asphalt-rubber surface mixes. Transportation Research Record: Journal of the Transportation Research Board, 1681 (1999), pp. 10-18.

[18] Xiang, L., Cheng, J., Kang, S.: Thermal oxidative aging mechanism of crumb rubber/SBS composite modified asphalt, Construction and Building Materials, 75 (2015), pp. 169-175

[19] Xiao, F., Amirkhanian, S., Juang, C.H.: Rutting resistance of rubberized asphalt concrete pavements containing reclaimed asphalt pavement mixtures, Journal of Materials in Civil Engineering, 19 (2007) 6, pp. 475-483.

[20] Šimun, M., Rukavina, T., Dimter, S.: Rutting resistance of waterproofing - asphalt pavement systems on bridges, Gradevinar, 65 (2013) 10, pp. 879-886

[21] Paje, S.E., Luong, J.L., Vázquez, V.F., Bueno, M., Miró, R.: Road pavement rehabilitation using a binder with a high content of crumb rubber - Influence on noise reduction, Construction and Building Materials, 47 (2013), pp. 789-798
[22] Franesqui, M., Yepes, J., García-González, C.: Improvement of moisture damage resistance and permanent deformation performance of asphalt mixtures with marginal porous volcanic aggregates using crumb rubber modified bitumen, Construction and Building Materials, 201 (2019), pp. 328-339

[23] Zhou, H., Holikatti, S., Vacura, P.: Caltrans use of scrap tires in asphalt rubber products: a comprehensive review. Journal of Traffic and Transportation Engineering (English Edition), 1 (2014) 1, pp. 39-48.

[24] Rasool, R., Wang, S., Zhang, Y., Li, Y., Zhang, G.: Improving the aging resistance of SBS modified asphalt with the addition of highly reclaimed rubber, Construction and Building Materials, 145 (2017), pp. 126-134

[25] Rasool, R., Song, P., Wang, S.: Thermal analysis on the interactions among asphalt modified with SBS and different degraded tire rubber, Constructions and Building Materials, 182 (2018), pp. 134-143

[26] Sri Wulandari, P., Tjandra, D.: Use of crumb rubber as an additive in asphalt concrete mixture, Procedia Engineering, 171 (2017), pp. 1384-1389

[27] http://hac.hr/hr/promet/brojanje-prometa, 17.10.2018.

[28] Brojanje prometa na cestama Republike Hrvatske godine 2016., Zagreb, 2017., Hrvatske ceste d.o.o.,in Croatian.

[29] https://hrvatske-ceste.hr/hr/pages/traffic_and_security/ documents/14-brojenje-prometa, 30.09.2018.

[30] Izvještaj br.: 2740-405/06, Izvještaj o kontrolnim ispitivanjima asfalterskih radova izvedenih na raskrižju Vukovarske avenije i izgradnji Sveučilišne aleje do ulice Lavoslava Ružičke, IGH d.d., Zagreb, lipanj 2006, in Croatian.

[31] Hrvatske Ceste i Hrvatske Autoceste: Opći tehnički uvjeti za radove na cestama, Institut Građevinarstva Hrvatske., Zagreb, lipanj 2001, in Croatian.

[32] HRN EN 12697-1 Bitumenske mješavine - Metode ispitivanja za asfalt proizveden vrućim postupkom - 1. dio: Topivi udio veziva

[33] HRN EN 12697-30 Bitumenske mješavine - Metode ispitivanja za asfalt proizveden vrućim postupkom - 30. dio: Priprema uzorka udarnim zbijačem

[34] HRN EN 12697-5 Bitumenske mješavine - Ispitne metode za asfalt proizveden vrućim postupkom - 5. dio: Određivanje gustoće asfaltne mješavine

[35] HRN EN 12697-6 Bitumenske mješavine - Metode ispitivanja za asfalt proizveden vrućim postupkom - 6. dio: Određivanje gustoće asfaltnih uzorka

[36] HRN EN 12697-8 Bitumenske mješavine - Ispitne metode za asfalt proizveden vrućim postupkom - 8. dio: Određivanje šupljina u asfaltnim uzorcima

[37] Ramljak, Z.: Izvještaj o proizvodnji, ugradnji i ispitivanju površine asfaltnog sloja načinjenog od asfalta tipa HS 8 K (SMA) VT(s) $\mathrm{M}$ sa doziranom pulveriziranom gumom ugrađenog u kolničku konstrukciju u Lučićevoj ulici u Zagrebu, Ramtech d.o.o., Zagreb, prosinac 2006.

[38] Ramljak, Z.: Primjena pulveriziranih otpadnih pneumatika u asfaltnoj cestogradnji, Ramtech d.o.o., Sesvetski Kraljevec, svibanj 2005.

[39] HRN EN 12697-36 Bitumenske mješavine - Ispitne metode za asfalt proizveden vrućim postupkom - 36. dio: Određivanje debljine asfaltnih slojeva u kolniku

[40] HRN EN 12697-22 Bitumenske mješavine - Ispitne metode za asfalt proizveden vrućim postupkom - 22 dio: Kolotraženje 
[41] HRN EN 13036-4:2012 Površinska svojstva cesta i aerodromskih operativnih površina - Metode ispitivanja - 4. dio: Metoda mjerenja otpornosti površine na klizanje: Ispitivanje klatnom

[42] HRN EN 13036-1 Površinska svojstva cesta i aerodromskih operativnih površina - Metode ispitivanja - 1. dio: Mjerenje dubine makroteksture površine kolnika volumetrijskim postupkom

[43] AGPT/T450 Determination of the International Roughness Indeks IRI using ARRB Walking Profiler

[44] HRN EN 13036-6 Površinska svojstva cesta i aerodromskih operativnih površina - Ispitne metode - 6 . dio: Mjerenje poprečnih i uzdužnih profila u području valnih duljina ravnosti i megateksture

[45] HRN EN 13108-5:2016 Bitumenske mješavine - Specifikacije materijala - 5. dio: SMA

[46] HRN EN 933-1 Ispitivanje geometrijskih svojstava agregata - 1. dio: Određivanje granulometrijskog sastava - Metoda sijanja
[47] HRN EN 933-2 Ispitivanje geometrijskih svojstava agregata - 2 . dio: Određivanje granulometrijskog sastava - Ispitna sita, nazivne veličine otvora

[48] HRN EN 12697-34 Bitumenske mješavine - Metode ispitivanja za asfalt proizveden vrućim postupkom - 34. dio: Marshallovo ispitivanje

[49] HRN EN 12697-12 Bitumenske mješavine - Metode ispitivanja-12. dio: Određivanje osjetljivosti asfaltnih uzoraka na vodu

[50] HRN EN 12697-23 Bitumenske mješavine - Metode ispitivanja 23. dio: Određivanje vlačne čvrstoće asfaltnih uzoraka neizravnom vlačnom metodom

[51] HRN EN 12697-26 Bitumenske mješavine - Ispitne metode za asfalt proizveden vrućim postupkom - 26. dio: Krutost 